\title{
Sustainable Intensification, community, and the Montpellier Panel: A meta-analysis of rhetoric in practice in sub-Saharan Africa
}

\author{
Anne M. Cafer a * \\ University of Mississippi \\ Hua Qin b \\ University of Missouri-Columbia
}

\begin{abstract}
Submitted September 19, 2016 / Revised January 24, May 8, and May 29, 2017 / Accepted May 21, 2017 /
Published online July 26, 2017

Citation: Cafer, A. M., \& Qin, H. (2017). Sustainable Intensification, community, and the Montpellier Panel: A meta-analysis of rhetoric in practice in sub-Saharan Africa. Journal of Agriculture, Food Systems, and Community Development, 7(3), 123-137. http://dx.doi.org/10.5304/jafscd.2017.073.008
\end{abstract}

Copyright (C) 2017 by New Leaf Associates, Inc.

\begin{abstract}
Agriculture-led economic development, an important policy driver in sub-Saharan Africa, requires both agricultural intensification and environmentally sustainable resource management. Sustainable Intensification (SI) provides a mechanism for achieving both. However, SI within an SSA context has yet to be widely examined in the scholarly literature; it has been confined instead to technical briefs and white papers. This metaanalysis, conducted in 2015, examines 58 articles that focus on SI in SSA published between 2001 and 2015 and listed in prominent research databases (EBSCOhost, Agricola, and Google Scholar). This analysis uses the 2013 Montpellier Framework

a * Corresponding author: Anne M. Cafer, PhD, Assistant Professor of Sociology, Department of Sociology and Anthropology, University of Mississippi; P.O. Box 1848; Room 543 Lamar Hall; University, Mississippi 38677 USA; +1-402-417-6960 or +1-662-915-5733; amcafer@olemiss.edu

b Hua Qin, PhD, Assistant Professor, Division of Applied Social Sciences, University of Missouri-Columbia; 216 Gentry Hall; Columbia, Missouri 65211 USA; qinh@missouri.edu
\end{abstract}

for Sustainable Intensification (Agriculture for Impact, 2013) to examine, critique, and find avenues for improvement in research within this emerging body of literature. Generally, the literature adheres to major concepts within the Montpellier framework, with the exception of community. Despite the prominence of community within the Montepellier framework, incorporation of community processes was often accidental. This analysis also reveals that major components of SI, such as nutrition, food security, and income, are poorly operationalized and make an assessment of SI's impact on socio-economic conditions and nutrition problematic. Based on this meta-analysis, the need for interdisciplinary engagement (a blending of biophysical and social scientists) is clear. Additionally, there is a demonstrable need for the inclusion of measurable concepts of community within SI processes or outcomes.

\section{Keywords}

Sustainable Intensification; Sub-Saharan Africa; Agricultural Development; Community; Natural Resource Management 


\section{Introduction}

Broadly speaking, agricultural development has been a catchall for any effort to improve the wellbeing of agrarian people and places. Within a subSaharan Africa (SSA) context, agricultural development is focused largely on improving the efficiency of production systems, with a trend emerging to combine community and household well-being into agricultural productivity interventions. To this end, sustainable intensification (SI), a process that combines improvements to agricultural productivity with improved livelihoods and increased resilience to shocks among agrarian households, has been emerging as a popular approach (Food and Agriculture Organization [FAO] of the United Nations, 2014). SI is popular among policy makers and politicians, yet there is a lack of meaningful dialogue about what SI is exactly and, more importantly, its effectiveness as an agricultural development tool (Food Ethics Council, 2012).

This study is a meta-analysis of the relatively small body of literature (58 articles) on SI projects. In this the meta-analysis we look at the extent to which major SI tenets are actually incorporated into SI projects on the ground and thus evaluate the use of SI theory in actual SI practice. This study specifically establishes the level or extent of incorporation of social, ecological, and genetic agricultural processes (three major SI tenets) and inventories the types of outcomes experienced by farmers and communities in SI projects. Given the importance of community in discussing natural resource management and agricultural livelihoods, we also examine how community is included in the scholarly literature on SI.

\section{Background}

In her address at the 2015 Association of International Agriculture and Rural Development conference, Terri Raney, chief editor and senior economist of The State of Food and Agriculture, a flagship report of the FAO, noted that "family farmers are the largest managers of natural resources" (Raney, 2015). This is particularly true for smallholders in SSA. Yet smallholders face increased pressures from general population growth within SSA, which are exacerbated by the demand for land to grow grain for protein and dairy production for the growing global middle class (FAO, 2014). These pressures often jeopardize the sustainable management of smallholder-controlled natural resources (FAO, 2014).

Historically, agricultural development has been used to attempt to balance yield production with income generation, resource management at the farm level, and food security for smallholders. This approach has generally focused on the technical and ecological aspects of agricultural development (Napier, 2010; Palsson, 1991; Rogers, 1995). However, in the most recent reiteration of development, specifically the 2016 United Nations Sustainable Development Goals, sustainability has emerged not only as a key indicator of success, but also as a unifying principle in development activities. Sustainability has traditionally been couched in natural resource management terms, with an emphasis on ecology and biophysical processes (Hopwood, Mellor, \& O’Brien, 2005). The 1987 Brundtland Report published by the World Commission on Environment and Development (WCED) ushered in a new era of sustainability defined in both ecological and social terms, which eventually gave way to the inclusion of socio-economic dimensions of sustainability (Hopwood et al., 2005; WCED, 1987). For the purposes of this analysis, sustainability incorporates elements of sustained economic and social well-being while reducing environmental impact (Agriculture for Impact, 2013).

Today, scholars, donors, and recipients acknowledge the critical importance of this more holistic concept of sustainability to agricultural development, and the role SI can potentially play in successful project implementation. SI is defined as being able to "produc[e] more outputs with more efficient use of all inputs_—on a durable basiswhile reducing environmental damage and building resilience, natural capital and the flow of environmental services" (Pretty, Toulmin, \& Williams, 2011, quoted in Agriculture for Impact, 2013, p. 11). SI is used within development as a means of accomplishing increased agricultural production while respecting the socio-cultural context of rural livelihoods in SSA. In fact, SI has provided a mechanism for incorporating a plethora of development agendas, including building capital (the U.S. Agency for International Development 
[USAID]'s 1992 community capitals perspective), improving resilience to climate change and ecological shocks, increasing stakeholder participation, building capacity, doing sustainable development, improving livelihoods, and increasing food security and nutrition (Agriculture for Impact, 2013; Carney, 1998; Luloff, Krannich, Theodori, Trentelman, \& Williams, 2004; Marshall, Fenton, Marshall, \& Sutton, 2007).

\section{The Community in Sustainable Intensification}

Community is often conceptualized as an interactional process among an ecologically bounded group of people where social interactions are necessarily shaped by the natural environment (Bridger \& Luloff, 1999; Wilkinson, 1991). The tension between the need to exploit the natural resource base for livelihood gains and maintaining and managing the resource base for future use has been well documented (Bridger \& Luloff, 1999). SI, though perhaps not originally designed to mitigate the conflicting goals of improved livelihoods and natural resource maintenance, could serve as a mechanism for accomplishing both while simultaneously empowering smallholders (Agriculture for Impact, 2013). In the SI framework (see Figure 1), the concept of community operates as a guiding mechanism, which differs from other sustainability frameworks in agriculture such as agroecology or conservation agriculture. Community and farmer are located at the center of the framework, around which sustainability measures, inputs, processes, and outcomes operate. Community ideally is incorporated into SI projects as a central guiding element. Priorities and the disciplinary backgrounds of SI practitioners, however, often limit the role of community in driving project design and implementation.

\section{Methods}

Systematic review and meta-analysis have been increasingly used to synthesize individual case studies in recent environmental and agricultural social science research (Qin \& Grigsby, 2016). This study of SI literature employed a meta-analysis of case studies approach, similar to Pagdee, Kim, and Daugherty (2006) and Rudel (2008). This meta- analysis identified the type(s) of intensification processes within each case study, as well as measured outcomes, and compared them to the SI framework proposed in the 2013 Montpellier Panel Report authored by Agriculture for Impact, Sustainable Intensification: A New Paradigm for African Agriculture (see Figure 1).

In this SI framework, the Montpellier Panel outlines very concrete aspects of four major domains: sustainable measures, inputs, intensification processes, and outputs. The sustainability measures domain includes, as examples, reduced greenhouse gas emissions and increased natural capital, as well as the efficient and prudent use of inputs. The inputs domain includes both direct (e.g., labor, water, chemicals, biodiversity, land) and indirect (e.g. financial capital, knowledge, infrastructure) inputs. In this model, direct inputs are used to produce the outputs of agriculture, while indirect inputs are used to facilitate or modify the use of direct inputs (Agriculture for Impact, 2013). The intensification process domain, one of the two domains this paper focuses on, includes three process: ecological (e.g., improved soil fertility), genetic (e.g., improved varieties), and socio-economic (e.g., enabling environments; market access). The last domain, also an area of focus for this paper, is outputs and includes production (e.g., increased yield), income, and nutrition (including food security). This study additionally examined the presence of community, a component of the model located at the center with "farmer," within the SI literature (Figure 1).

\section{Selection of Articles}

SI is necessarily an interdisciplinary scholarly endeavor. Yet a significant amount of the literature remains in the biophysical disciplines or unpublished in grey literature and technical reports. Because scholarly literature often serves as a benchmark for how accepted a particular framework or paradigm is, this study focused only on scholarly literature. We conducted an initial search of the literature in 2015. Only articles published between 2000 and the current year in EBSCOhost, AGRICOLA, and Google Scholar were considered. Using key words "sustainable intensification" AND "sub-Saharan Africa" resulted in 682 articles. 


\section{Figure 1. Montpellier Panel Theoretical Model of Sustainable Intensification}

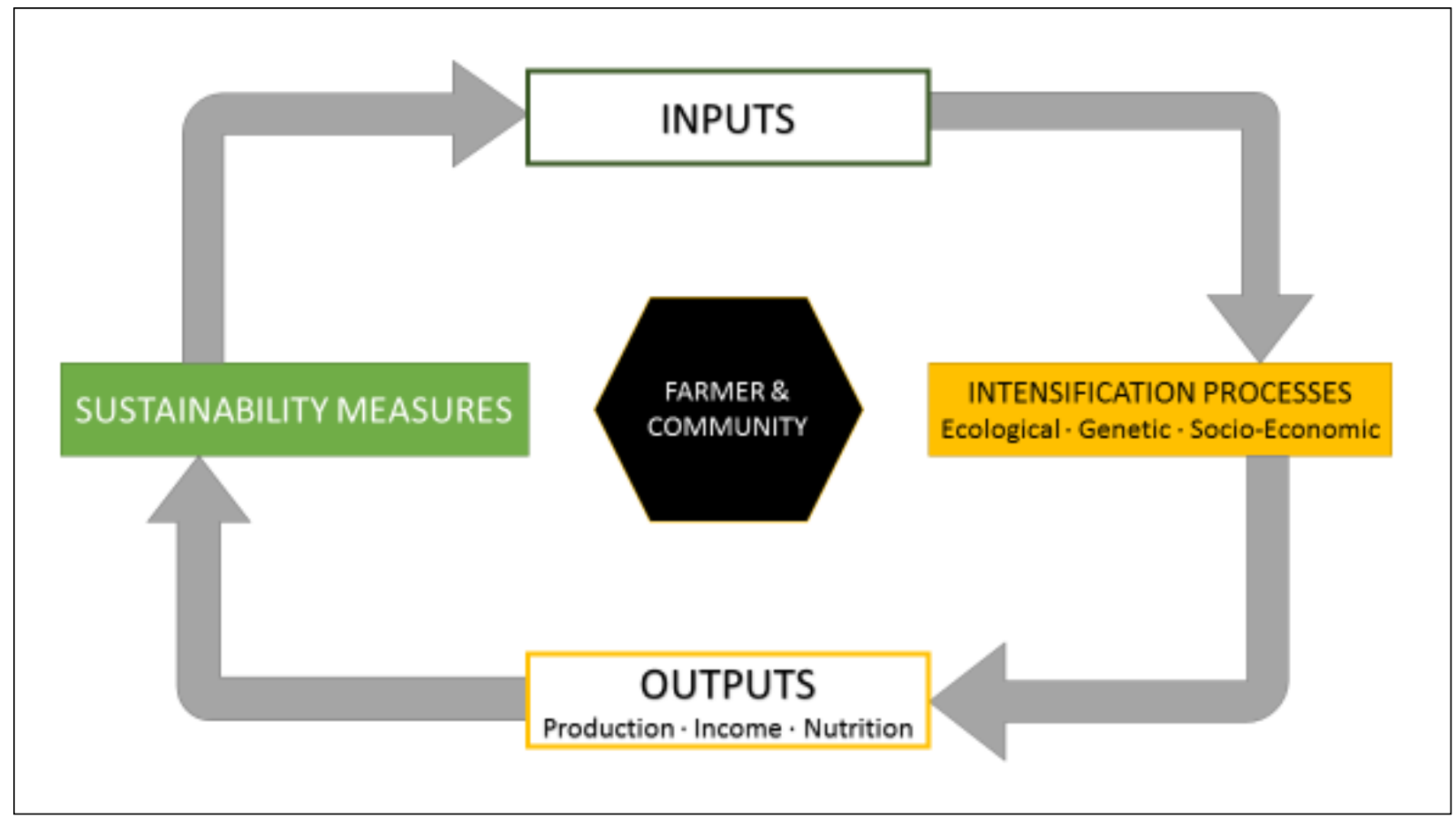

Adapted from Agriculture for Impact, 2013, p. 12.

We narrowed the search results by excluding specific search terms (India, Asia, Reviews, Agricultural Policy, China, Agricultural Economics Policy). The exclusion of these search terms filtered out results from non-SSA geographic regions and those focused primarily on theoretical and policy debates, and resulted in 140 articles. We scanned each of these articles for the use of primary research (i.e., simulated models and theoretical pieces were excluded) as well as the inclusion of at least one of the outcomes outlined in the Montpellier Report: production, income, or nutrition. This final scan narrowed the 140 to 58 articles (see the Appendix for the full list of included studies).

\section{Coding of Selected Cases}

As the primary purpose of this meta-analysis was to attempt to determine if scholarly articles on SI projects possessed all the ideal components as published in the Montpellier Panel report, each of the process categories and potential outputs was coded as a binary variable. Articles that discussed aspects of each process (see Agriculture for Impact, 2013) — genetic, ecological, and/or socio-economic- were coded as " 1 " or, if they did not, they were coded as " 0 ." This generated an initial SPSS file containing six binary variables. For each of the types of processes and outcomes, the Montpellier Panel report allows for several subtypes. In an effort to determine if projects generally fit the Montpellier Panel framework, we conducted a subtype inventory to determine the specific subtype used by researchers either within the design of the study (process of intensification) or within the discussion of outcomes. For example, the Montpellier report allows for several different subtypes of genetic processes, such as improved varieties, breeding, and drought resistance. For each article where genetic processes were used, we made a note to indicate the specific subtype of genetic intensification.

Community was also coded as a binary variable (" 1 " for presence of community engagement or " 0 " for no presence in the description of the study). We also included another variable indicating the employment of participatory methods ("1" = yes, " 0 " = no). It is important to note that a research team may very well have included aspects of community engagement in its study but did not 
include it in the description of the research process. Additionally, the disciplinary toolkit available to the research team may have prohibited a systematic inclusion of community in the research design. Though this limits the types of conclusions that can be drawn about the implementation of SI, it may speak to a larger (non)narrative on community engagement in academic research.

We used IBM SPSS Statistics 21 to run chisquared analysis on the intensification processes and outcomes as well as the presence of community engagement and the use of participatory methods within this set of articles. We ran crosstabs on individual processes and outcomes together and then included the community and participatory approach variables. We conducted this analysis to explore the linkages between the types of processes used in the intervention and potential outcomes outlined by the Montpellier Panel as well as their connections with the incorporation of community engagement and participatory methods. Because the nature of this study is exploratory rather than explicative, we did not do additional analysis on these relationships.

\section{Results}

\section{Descriptive Analysis}

Of the 58 articles selected for analysis, 22 included some aspect of genetic intensification, 47 included ecological intensification subtypes, and 50 included elements of socio-economic intensification (Table 1). Only three articles did not discuss production outcomes, 42 discussed increases in income (or other economic issues), and only 22 discussed nutrition (or food security).

Descriptive analysis revealed some general trends, namely, that genetic and ecological intensification, though not mutually exclusive, often did not occur together. There were only 14 articles
(24\%) where both genetic and ecological intensification were utilized, and less than $40 \%$ of projects measured some aspect of nutrition. Additionally, we conducted subtype analysis using simple counts. Subtype inventory revealed that most articles discussed the same aspects of genetic, ecological, and socio-economic intensification and outcome categories used in the Montpellier framework. However, there were three notable exceptions. The first was the deliberate inclusion of community within the socio-economic intensification category. Five studies clearly indicated that a portion of the project was focused on community (community development; community infrastructure; community of practice; collective action; community resilience). Because community was not well defined in many of these studies, and, studies that incorporated the use of social capital development were also included in the community subtype for statistical analysis purposes (Gittell \& Videl, 1998). The second exception is the inclusion of school fees as a potential outcome within the "income" category. The third exception was the inclusion of nutrientspecific measures of the nutrition outcome. Generally speaking, this particular outcome was often measured broadly as either improved consumption or improved access to food.

Perhaps just as important as what was included are the things missing from a large number of articles. Many of the articles mention or allude to "improved food security" or "improved nutrition," but fail to conduct a systematic investigation into the actual extent of improvement. In many cases, it is assumed that increases in income will translate to improved food security status or improved household nutrition.

Bivariate Analysis

Chi-squared analysis revealed a number of significant relationships between intensification

Table 1. Frequency of Intensification Processes and Outcomes in Sample

\begin{tabular}{|c|c|c|c|c|c|c|c|c|}
\hline \multicolumn{4}{|c|}{ Intensification Processes } & \multicolumn{3}{|c|}{ Intensification Outcomes } & \multirow[b]{2}{*}{ Community } & \multirow[b]{2}{*}{$\begin{array}{l}\text { Participatory } \\
\text { Methods }\end{array}$} \\
\hline Genetic & Ecological & $\begin{array}{l}\text { Socio- } \\
\text { Economic }\end{array}$ & $\begin{array}{l}\text { Genetic + } \\
\text { Ecological }\end{array}$ & Production & Income & Nutrition & & \\
\hline $\begin{array}{c}22 \\
(37.9 \%)\end{array}$ & $\begin{array}{c}47 \\
\text { (81.0\%) }\end{array}$ & $\begin{array}{c}50 \\
(86.2 \%)\end{array}$ & $\begin{array}{c}14 \\
(24.1 \%)\end{array}$ & $\begin{array}{c}55 \\
\text { (94.8\%) }\end{array}$ & $\begin{array}{c}42 \\
(72.4 \%)\end{array}$ & $\begin{array}{c}22 \\
(37.9 \%)\end{array}$ & $\begin{array}{c}19 \\
(32.8 \%)\end{array}$ & $\begin{array}{c}26 \\
(44.8 \%)\end{array}$ \\
\hline
\end{tabular}


processes and outcomes, as well as between processes and the use of participatory methods of engagement. Programs or projects that utilized genetic intensification processes were also more likely to utilize participatory methods. In many cases, the implementation of programs or projects focused on genetic intensification, which were often focused on breeding crops or livestock, and thus required researchers to conduct on-farm experiments with farmers. In these cases, researchers utilized local farmers' expertise to determine which varieties, characteristics, or breeding lines were most suitable to the agroecological context, which necessitated farmer participation. Perhaps not surprisingly, but nevertheless important, we found that ecological intensification processes were significantly likely to result in production outcomes, while socioeconomic intensification processes were likely to result in income outcomes. Somewhat surprising, and perhaps indicative of the funding climate, genetic, ecological, and socioeconomic intensification processes were significantly likely to produce, or at least discuss, nutrition outcomes. Community was not significantly likely to be included in any of the types of intensification process (specific results not included in Table 2) or significantly associated with any of the various types of outcomes, but was significantly associated with projects or research where participatory methods were employed.

\section{Discussion}

This meta-analysis was conducted in an effort to determine if scholarly literature based on SI projects reflected the tenets of the SI framework, notably the framework published in the Montpellier Panel report (see Figure 1). This study specifically examined the presence of the three types of intensification (genetic, ecological, and socio-economic), as well as the desired outcomes of an "ideal" SI project: increased production and income, and better nutrition. Each of the proposed projects discussed at least one of the SI processes and at least one SI outcome according to the subtype inventory. In addition, this collection of 58 articles included all of the aspects of the Montpellier SI framework, including community, suggesting that the scholarly literature generally reflects the intent of SI. However, the extent of inclusion, the level of analysis, and the unintentional inclusion of community provides room for a brief critique.

\section{Inclusion (or Not) of Community}

The first critique is not a new one in the arena of development or natural resource management.

Table 2. Associations Between Major Variables $(N=58)^{a}$

\begin{tabular}{|c|c|c|c|c|}
\hline \multirow{2}{*}{ Intensification Process } & \multicolumn{3}{|c|}{$\begin{array}{l}\text { Number of Studies Combining “ } X \text { " Intensification Process } \\
\text { and " } X \text { " Outcome }\end{array}$} & \multirow{2}{*}{$\begin{array}{l}\text { Participatory Methods Used } \\
\text { ( } \chi^{2} \text { statistic) }\end{array}$} \\
\hline & $\begin{array}{l}\text { Production } \\
\left(\chi^{2} \text { statistic }\right)\end{array}$ & $\begin{array}{c}\text { Income } \\
\left(\chi^{2} \text { statistic }\right)\end{array}$ & $\begin{array}{c}\text { Nutrition } \\
\left(\chi^{2} \text { statistic }\right)\end{array}$ & \\
\hline Genetic Intensification & $\begin{array}{c}20 \\
(1.110)\end{array}$ & $\begin{array}{c}18 \\
(1.569)\end{array}$ & $\begin{array}{c}12 * \\
(4.156)\end{array}$ & $\begin{array}{c}14 * \\
(5.070)\end{array}$ \\
\hline Ecological Intensification & $\begin{array}{c}47 * * * \\
(13.517)\end{array}$ & $\begin{array}{c}35 \\
(0.524)\end{array}$ & $\begin{array}{c}14 * * \\
(6.981)\end{array}$ & $\begin{array}{c}21 \\
(0.002)\end{array}$ \\
\hline Socio-Economic Intensification & $\begin{array}{c}47 \\
(0.506)\end{array}$ & $\begin{array}{c}40 * * * \\
(10.443)\end{array}$ & $\begin{array}{l}22 * \\
(5.671)\end{array}$ & $\begin{array}{c}24 \\
(1.475)\end{array}$ \\
\hline $\begin{array}{l}\text { Both Genetic + Ecological } \\
\text { Intensification }\end{array}$ & $\begin{array}{c}14 \\
(5.621)\end{array}$ & $\begin{array}{c}13 \\
(3.862)\end{array}$ & $\begin{array}{l}6 \\
(1.446)\end{array}$ & $\begin{array}{c}9 \\
(4.768)\end{array}$ \\
\hline Community & $\begin{array}{c}18 \\
(0.983)\end{array}$ & $\begin{array}{c}15 \\
(0.604)\end{array}$ & $\begin{array}{c}7 \\
(0.014)\end{array}$ & $\begin{array}{l}16 * * * \\
(17.720)\end{array}$ \\
\hline
\end{tabular}

a Given as the numbers of sample studies combing different study characteristics. For example, 20 studies included both "Genetic Intensification" process and "Production" outcome.

$* p<.05, * * p<.01, * * * p<.001$ 
Concepts of community historically are missing from meaningful analyses of ecological management or development (Flint, Luloff, \& Finley, 2008; Glasmeier \& Farrigan, 2005). In this study, only five articles specifically included elements of community, either through community development in general or through facilitating collective action or improving community infrastructure (see a list of all 58 papers in this meta-analysis in the Appendix; also see Andersson \& Gabrielsson, 2012; Asaah et al., 2011; Peacock \& Hastings, 2011; Silici et al., 2011; Wambugu et al., 2011). The remainder of the articles either failed to mention community or else discussed community engagement at a superficial level, such as having farmers plant new varieties for on-farm trials (but not participating in the research process or providing feedback on community or farmers' perceptions of the new variety). Rarely is there a concerted effort to facilitate community change. Rather, many of these projects appear to act upon community as an afterthought. On a macro level, community serves as a theoretical driver for the conceptualization and justification of SI. In this critique, it becomes apparent that the relatively amorphous guiding principle of "community" fails to provide a mechanism for purposefully addressing community within SI projects. Rather than a guiding principle, community development should be an established, well-defined, measurable outcome. The Community Capitals Framework provides a useful starting point for determining the impact of projects on community well-being. This includes assessments of improved capacities in managing natural capital and cultural capital, as well as building or establishing human, social, political, financial, and built capital (Fey, Bregendahl, \& Flora, 2006).

Because a community is not just a group of individuals but also their social interactions contextualized and bounded by the ecological environment, long-term change in resource management and sustainable agricultural practices requires a shift in how researchers view SI implementation and practice. Sustained use of SI by smallholders will, therefore, require researchers to push beyond the elementary implementation of projects in a community setting and systematically work toward purposeful midlevel integration and eventually to utilize community in the theoretical motivations for developing, implementing, and analyzing SI projects.

\section{Nutrition or Food Security?}

The second major critique of this subset of articles is their failure to systematically explore the outcomes of these projects in terms of nutrition. The Montpellier Panel provides maximum latitude in terms of assessing nutrition - from dietary diversity to an increase in consumption to an increase in production of staple food crops. Yet only 22 of the 58 articles attempted to assess improvements in nutrition related to SI processes. In reading the articles more closely, this is likely the product of two problems. The first is a lack of familiarity with standard measures of nutritional assessment on the part of researchers involved in the project. The second is an assumption that increased revenues from crops or livestock, usually male-controlled resources, will necessarily translate to improved household nutrition, making the systematic measurement of nutrition unnecessary. Studies have clearly demonstrated that gains in income do not necessarily translate to improved household nutritional status if men control these resources, though it may lead to improvements in living conditions, materials goods, and education (Blaney, Beaudry, \& Latham, 2009; Quisumbing, 2003).

The first problem is easily remedied by some minor adjustments to the framework. Nutrition has been systematically studied in Africa for decades, and several models exist for measuring those aspects of nutrition outlined in the model, with dietary diversity and energy intake being the most common (see Carletto, Zezza, \& Banerjee, 2013; DeHaen, Klasen, \& Qaim, 2011; Dowler \& Seo, 1985; and Masset, 2011). However, given that many of these measurements are not readily accessible conceptually to those outside of the nutrition and health sciences disciplines, there are other universal measures of nutritional status. One example is body mass index (BMI), a relatively simple calculation that uses the subject's height and weight and for which there are regional standards developed by the World Health Organization (2013). Incorporating additional project personnel who are familiar with nutritional assessment could solve both 
barriers to proper nutritional assessment.

The juxtaposition of nutrition and food security in this particular literature, as well as agricultural development literature generally, in addition to the current funding climate, suggests that the Montpellier Panel might consider replacing nutrition with food security or add food security as an additional outcome. Initiatives such as Feed the Future recently have placed emphasis on food security, which, as a precursor to proper nutrition and the first battle to be fought in the war against malnutrition, has been given top priority. Most of the 22 articles (Table 1), with the exception of six, discussed nutrition in terms of food security. Yet again there was a general failure to assess food insecurity in a systematic manner. A wellestablished tool, the Household Food Insecurity Access Scale (HFIAS) v.3, is a nine-question survey tool used to measure perceptions of food insecurity, such as reduced quality or quantities of food and fear of going without food for periods of time. This tool is used almost universally by U.S. federal agencies working abroad and has been validated in cross-cultural contexts (Coates, Swindale, \& Bilinsky, 2007). Using this food insecurity assessment would provide a mechanism for establishing baseline data as well as evaluating the success of various SI projects' impacts on household food security.

\section{Social Science Imposter}

This meta-analysis has revealed perhaps a deeper issue, which has contributed overwhelmingly to the previous two critiques. Though many of the teams writing these articles are interdisciplinary, there are few social scientists involved in the projects' design or implementation. Rather, scholars in disciplines far outside the social sciences seek to explain these phenomena in an act of disciplinary imperialism (Olsson, Jerneck, Thoren, Persson, \& O’Byrne, 2015). The lack of understanding of the social sciences has resulted in problematic interpretations of outcomes associated with both nutrition and, to some extent, income.

\section{Conclusion}

SI's versatility has placed it at the forefront of agricultural development, particularly within the
sub-Saharan African context, yet it has remained mostly outside the purview of academic dialogue. SI shows great potential for integrated ecological management while simultaneously embracing the social norms that exist within the socio-ecological system. Fulfillment of this potential through purposeful integration of community stakeholders and operationalization of community concepts in project design will increase SI's ability to promote community resilience and smallholder empowerment. Through increased intentional stakeholder involvement via strengthened community development components of the framework, SI can help promote local ideals within the food system and mitigate outside and "expert" influences on smallholder livelihoods and production practices.

\section{References}

Agriculture for Impact. (2013). Sustainable Intensification: A new paradigm for African agriculture (A 2013

Montpellier Panel report). London: Author. Retrieved from http://ag4impact.org/publications/ montpellier-panel-report2013/

Blaney, S., Beaudry, M., \& Latham, M. (2009). Determinants of undernutrition in rural communities of a protected area in Gabon. Public Health Nutrition, 12(10), 1711-1725. https://doi.org/10.1017/S1368980008004035

Bridger, J. C., \& Luloff, A. E. (1999). Toward an interactional approach to sustainable community development. Journal of Rural Studies, 15(4), 377-387. https://doi.org/10.1016/S0743-0167(98)00076-X

Carletto, C., Zezza, A., \& Banerjee, R. (2013). Towards better measurement of household food security: Harmonizing indicators and the role of household surveys. Global Food Security, 2(1), 30-40. https://doi.org/10.1016/j.gfs.2012.11.006

Carney, D. (1998). Sustainable rural livelihoods: What contribution can we make? London: Department for International Development.

Coates, J., Swindale, A., \& Bilinsky, P. (2007). Household Food Insecurity Access Scale (HFLAS) for measurement of food access: Indicator guide, version 3. Washington, D.C.: FANTA/FHI 360. Retrieved from https://www. fantaproject.org/monitoring-and-evaluation/ household-food-insecurity-access-scale-hfias 
De Haen, H., Klasen, S., \& Qaim, M. (2011). What do we really know? Metrics for food insecurity and undernutrition. Food Policy, 36(6), 760-769. https://doi.org/10.1016/i.foodpol.2011.08.003

Dowler, E. A., \& Seo, Y. O. (1985). Assessment of energy intake: Estimates of food supply $v$ measurement of food consumption. Food Policy, 10(3), 278-288. https://doi.org/10.1016/03069192(85)90066-1

Fey, S., Bregendahl, C., \& Flora, C. (2006). The measurement of community capitals through research. Online Journal of Rural Research and Policy, 1(1). http://dx.doi.org/10.4148/ojrrp.v1i1.29

Flint, C. G., Luloff, A. E., \& Finley, J. C. (2008). Where is "community" in community-based forestry? Society and Natural Resources: An International Journal, 21(6), 526-537. https://doi.org/10.1080/08941920701746954

Food Ethics Council. (2012). Sustainable intensification: Unravelling the rhetoric. Food Ethics, 7(2), 1-30. Retrieved from http://www.foodethicscouncil.org

Food and Agriculture Organization [FAO] of the United Nations. (2014). The state of food and agriculture 2014: Innovation in family farming. Rome: Author. Retrieved from http://www.fao.org/publications/sofa/2014/ en $/ ? \% 25 \mathrm{DCa} \% 25 \mathrm{~B} 0 \% 2507$

Gittell, R., \& Videl, A. (1998). Community organizing: Building social capital as a development strategy. Thousand Oaks, California: SAGE.

Glasmeier, A. K., \& Farrigan, T. (2005). Understanding community forestry: A qualitative meta-study of the concept, the process, and its potential for poverty alleviation in the United States case. The Geographical Journal, 171(1), 56-69. https://doi.org/10.1111/j.1475-4959.2005.00149.x

Hopwood, B., Mellor, M., \& O’Brien, G. (2005). Sustainable development: Mapping different approaches. Sustainable Development, 13(1), 38-52. https://doi.org/10.1002/sd.244

Luloff, A.E., Krannich, R., Theodori, G., Trentelman, C.K., \& Williams, T., (2004). The use of community in natural resource management. In M. J. Manfredo, J. J. Vaske, B. L. Bruyere, D. R. Field, \& P. J. Brown (Eds.), Society and Natural Resources: $A$ Summary of Knowledge (pp. 249-259). Jefferson, Missouri: Modern Litho.

Marshall, N. A., Fenton, D. M., Marshall, P. A., \& Sutton, S. G. (2007). How resource dependency can influence social resilience within a primary resource industry. Rural Sociology, 72(3), 359-390. http://onlinelibrary.wiley.com/journal/10.1111/(IS SN)1549-0831

Masset, E. (2011). A review of hunger indices and methods to monitor country commitment to fighting hunger. Food Policy, 36(Supp. 1), S102-S108. https://doi.org/10.1016/j.foodpol.2010.11.007

Napier, T. L. (2010). Human dimensions of conservation adoption behaviors: The United States experience. In T. L. Napier (Ed.), Human Dimensions of Soil and Water Conservation: A Global Perspective (pp. 31-45). New York: Nova Science.

Olsson, L., Jerneck, A., Thoren, H., Persson, J., \& O’Byrne, D. (2015). Why resilience is unappealing to social science: Theoretical and empirical investigations of the scientific use of resilience. Science Advances, 1(4), e1400217. https://doi.org/10.1126/sciadv.1400217

Pagdee, A., Kim, Y.-S., \& Daugherty, P. J. (2006). What makes community forest management successful: A meta-study from community forests throughout the world. Society and Natural Resources, 19(1), 33-52. https://doi.org/10.1080/08941920500323260

Palsson, G. (1991). Coastal Economies, Cultural Accounts: Human Ecology and Icelandic Discourse. Manchester: Manchester University Press.

Qin, H., \& Grigsby, M. E. (2016). A systematic review and "meta-study" of meta-analytical approaches to the human dimensions of environmental change. Human Ecology Review, 22(2), 109-136. https://dx.doi.org/10.22459/HER.22.02.2016.05

Quisumbing, A.R. (2003). Food aid and child nutrition in rural Ethiopia. World Development, 31(7), 1309_ 1324. https://doi.org/10.1016/S0305750X(03)00067-6

Raney, T. (2015, May-June). Innovation in family farming: An FAO perspective. Keynote presentation at Association of International Agriculture and Rural Development, Washington, D.C.

Rogers, E. M. (1995). Diffusion of innovations: Modifications of a model for telecommunications. In M. W. Stoetzer, \& A. Mahler (Eds.), Die Diffusion von Innovationen in der Telekommunikation (pp. 25-38). Berlin \& Heidelberg: Springer. https://doi.org/10.1007/978-3-642-79868-9 2 
Rudel, T. K. (2008). Meta-analyses of case studies: A method for studying regional and global environmental change. Global Environmental Change, 18(1), 18-25.

https://doi.org/10.1016/i.gloenvcha.2007.06.001

U.S. Agency for International Development [USAID]. (1992). US AID policy determination: Definition of food security (PD-19). Washington, D.C.: Author. Retrieved from http://pdf.usaid.gov/pdf docs/Pnaav468.pdf

Wilkinson, K. P. (1991). The community in rural America. Westport, Connecticut: Greenwood.

World Commission on Environment and Development [WCED]. (1987). Our common future. Oxford: Oxford University Press.

World Health Organization. (2013). Trade, foreign policy, diplomacy, and health: Food security. Geneva: Author. 


\section{Appendix. Studies Included in this Meta-analysis}

Adegbidi, A., Gandonou, E., \& Oostendrop, R. (2004). Measuring the productivity from indigenous soil and water conservation technologies with household fixed effects: A case study of hilly mountainous areas of Benin. Economic Development and Cultural Change, 52(2), 313-346. http://dx.doi.org/10.1086/381018

Ajayi, O., Place, F., Akinnifesi, F., \& Sileshi, G. W. (2011). Agricultural success from Africa: The case of fertilizer tree systems in southern Africa (Malawi, Tanzania, Mozambique, Zambia and Zimbabwe). International Journal of Agricultural Sustainability, 9(1), 129-136. https://doi.org/10.3763/ijas.2010.0554

Andersson, E., \& Gabrielsson, S. (2012). 'Because of poverty, we had to come together': Collective Action for improved food security in rural Kenya and Uganda. International Journal of Agricultural Sustainability, 10(3), 245-262. https://doi.org/10.1080/14735903.2012.666029

Asaah, Ebenezar, Zacharie Tchoundjeu, Roger Leakey, Bertin Takousting, James Njong and Innocent Edang. (2011). Trees, agroforestry and multifunctional agriculture in Cameroon. International Journal of Agricultural Sustainability, 9(1), 110-119. https://doi.org/10.3763/ijas.2010.0553

Assefa, K., Aliye, S., Belay, G., Metaferia, G., Tefera, H., \& Sorrells, M. (2011). Quncho: The first popular tef variety in Ethiopia. International Journal of Agricultural Sustainability, 9(1), 25-34. https://doi.org/10.3763/ijas.2010.0545

Baudron, F., Jaleta, M., Okitoi, O., \& Tegegn, A. (2014). Conservation agriculture in African mixed croplivestock systems: Expanding the niche. Agriculture, Ecosystems and Environment, 187(1), 171-182. http://dx.doi.org/10.1016/j.agee.2013.08.020

Becker, M., \& Johnson, D. E. (2001). Cropping intensity effects on upland rice yield and sustainability in West Africa. Nutrient Cycling in Agroecosystems, 59, 107-117. https://doi.org/10.1023/A:1017551529813

Bellwood-Howard, I. (2012). Donkeys and bicycles: Capital interactions facilitating timely compost application in northern Ghana. International Journal of Agricultural Sustainability, 10(4), 315-327. https://doi.org/10.1080/14735903.2012.666030

Brummett, R., \& Jamu, D. (2011). From researcher to farmer: Partnerships in integrated aquacultureagriculture systems in Malawi and Cameroon. International Journal of Agricultural Sustainability, 9(1), 282289. https://doi.org/10.3763/ijas.2010.0570

Dorward, A., \& Chirwa, E. (2011). The Malawi Agricultural Input Subsidy Programme: 2005/06 to 2008/09. International Journal of Agricultural Sustainability, 9(1), 232-247. https://doi.org/10.3763/ijas.2010.0567

Fofana, B., Tamelokpo, A., Wopereis, M. C. S., Breman, H., Dzotsi, K., \& Carsky, R. J. (2005). Nitrogen use efficiency by maize as affected by a mucuna short fallow and $\mathrm{p}$ application in the coastal savanna of West Africa. Nutrient Cycling in Agroecosystems, 71, 227-237. http://dx.doi.org/10.1007/s10705-004$\underline{5084-0}$

Giller, K., Murwira, M., Dhliwayo, D., Mafongoya, P., \& Mpepereki, S. (2011). Soyabeans and sustainable agriculture in southern Africa. International Journal of Agricultural Sustainability, 9(1), 50-58. https://doi.org/10.3763/ijas.2010.0548

Gockowski, J., \& Sonwa, D. (2011). Cocoa intensification scenarios and their predicted impact on $\mathrm{CO}_{2}$ Emissions, biodiversity conservation, and rural livelihoods in the Guinea Rain Forest of West Africa. http://dx.doi.org/10.1007/s00267-010-9602-3 
Guei, R., Barra, A., \& Silue, D. (2011). Promoting smallholder seed enterprises: Quality seed production of rice, maize, sorghum and millet in Northern Cameroon. International Journal of Agricultural Sustainability, 9(1), 91-99. https://doi.org/10.3763/ijas.2010.0573

Guyver, P., \& MacCarthy, M. (2011). The Ghana Grains Partnership. International Journal of Agricultural Sustainability, 9(1), 35-41. https://doi.org/10.3763/ijas.2010.0564

Homann-Kee Tui, S., Valubuena, D., Masikati, P., Descheemaeker, K., Nyamangara, J., Claessens, L., Erenstein, O., van Rooyen, A., \& Nkomboni, D. (2015). Economic trade-offs of biomass use in crop-livestock systems: Exploring more sustainable options in semi-arid Zimbabwe. Agricultural Systems, 134, 48-60. http://dx.doi.org/10.1016/j.agsy.2014.06.009

Hounkonnou, D., Kossou, D., Kuyper, T., Leeuwis, C., Nederlof, E. S., Roling, N., ... van Huis, A. (2012). An innovation systems approach to institutional change: Smallholder development in West Africa. Agricultural Systems, 108, 74-83. https://doi.org/10.1016/j.agsy.2012.01.007

Jaleta, M., Kassie, M., \& Shiferaw, B. (2013). Tradeoffs in crop residue utilization in mixed crop-livestock systems and implications for conservation agriculture. Agricultural Systems, 121, 96-105. http://dx.doi.org/10.1016/j.agsy.2013.05.006

Jepson, P. C., Guzy, M., Blaustein, K., Sow, M., Sarr, M., Mineau, P., \& Kegley, S. (2014). Measuring pesticide ecological and health risks in West African agriculture to establish an enabling environment for Sustainable Intensification. Philosophical Transactions of The Royal Society B Biological Sciences, 369(1639), 20130491. http://dx.doi.org/10.1098/rstb.2013.0491

Kamiri, H., Kreye, C., \& Becker, M. (2013). Dynamics of agricultural use differentially affect soil properties and crop response in East African wetlands. Wetlands Ecology Management, 21, 417-431. http://dx.doi.org/10.1007/s11273-013-9315-5

Kebebe, E. G., Oosting, S. J., Haileslassie, A., Duncan, A. J., \& de Boer, IJM. (2015). Strategies for improving water use efficiency of livestock production in rain-fed systems. Animal, 9(5), 908-916. http://dx.doi.org/10.1017/S1751731114003115

Kent, R., Johnson, D. E., \& Becker, M. (2001). The influences of cropping system on weed communities of rice in Cote d'Ivoire, West Africa. Agriculture, Ecosystems and Environment, 87(3), 299-307. http://dx.doi.org/10.1016/S0167-8809(01)00153-0

Kiara, J. (2011). Focal area approach: A participator community planning approach to agricultural extension and market development in Kenya. International Journal of Agricultural Sustainability, 9(1), 232-247. https://doi.org/10.3763/ijas.2010.0566

Khan, Z., Midega, C., Pttchar, J., Pickett, J., \& Bruce, T. (2011). Push-pull technology: A conservation agriculture approach for integrated management of insect pests, weeds, and soil health in Africa. International Journal of Agricultural Sustainability, 9(1), 162-170. https://doi.org/10.3763/ijas.2010.0558

Liebenehm, S., Affognon, H., \& Waibel, H. (2011). Collective livestock research for sustainable disease management in Mali and Burkina Faso. International Journal of Agricultural Sustainability, 9(1), 212-221. https://doi.org/10.3763/ijas.2010.0572

Manlay, R., Masse, D., Chotte, J.-L., Feller, C., Kaire, M., Fardoux, J., \& Pontanier, R. (2002). Carbon, nitrogen, and phosphorus allocation in agro-ecosystems of a West African savanna: II. The soil component under semi-permanent cultivation. Agriculture, Ecosystems, \& Environment, 88(3), 233-248. http://dx.doi.org/10.1016/S0167-8809(01)00219-5 
Manlay, R., Kaire, M., Masse, D., Luc Chotte, J.-L., Ciornei, G., \& Floret, C. (2002). Carbon, nitrogen and phosphorus allocation in agro-ecosystems of a West African savanna: I. The plant component under semi-permanent cultivation. Agriculture, Ecosystems and Environment, 88(3), 215-232. http://dx.doi.org/10.1016/S0167-8809(01)00218-3

Marongwe, L., Kwazira, K., Jenrich, M., Thiefelder, C., Kassam, A., \& Friedrich, T. (2011). An African success: The case of conservation agriculture in Zimbabwe. International Journal of Agricultural Sustainability, 9(1), 153-161. https://doi.org/10.3763/ijas.2010.0556

Matous, P., Todo, Y., \& Mojo, D. (2013). Roles of extension and ethno-religious networks in acceptance of resource-conserving agriculture among Ethiopian farmers. International Journal of Agricultural Sustainability, 11(4), 301-316. https://doi.org/10.1080/14735903.2012.751701

Mhango, W., Snapp, S., \& Phiri, G. (2012). Opportunities and constraints to legume diversification for sustainable maize production on smallholder farms in Malawi. Renewable Agriculture and Food Systems, 28(3), 234-244. http://dx.doi.org/10.1017/S1742170512000178

Miller, J., \& Atanda, T. (2011). The rise of peri-urban aquaculture in Nigeria. International Journal of Agricultural Sustainability, 9(1), 274-281. https://doi.org/10.3763/ijas.2010.0569

Mitei, Z. (2011). Growing sustainable tea on Kenyan smallholder farms. International Journal of Agricultural Sustainability, 9(1), 59-66. https://doi.org/10.3763/ijas.2010.0550

Muhanji, G., Roothaert, R., Webo, C., \& Stanley, M. (2011). African indigenous vegetable enterprises and market access for small-scale farmers in East Africa. International Journal of Agricultural Sustainability, 9(1), 194-202. https://doi.org/10.3763/ijas.2010.0561

Mwanga, R., \& Ssemakula, G. (2011). Orange-fleshed sweetpotatoes for food, health and wealth in Uganda. International Journal of Agricultural Sustainability, 9(1), 42-49. https://doi.org/10.3763/ijas.2010.0546

Owenya, M., Mariki, W., Kienzle, J., Friedrich, T., \& Kassam, A. (2011). Conservation Agriculture (CA) in Tanzania: The case of the Mwangaza B CA Farmer Field School (FFA), Rhotia Village, Karatu District, Arusha. International Journal of Agricultural Sustainability, 9(1), 145-152. https://doi.org/10.3763/ijas.2010.0557

Payne, W., Tapsoba, H., Baoua, I., Malick, B., N’Diaye, M., \& Dabire-Binso, C. (2011). On-farm biological control of the pearl millet head miner: Realization of 35 years of unsteady progress in Mali, Burkina Faso and Niger. International Journal of Agricultural Sustainability, 9(1), 186-193. https://doi.org/10.3763/ijas.2010.0560

Peacock, C., \& Hastings, T. (2011). Meru Dairy Goat and Animal Healthcare Project. International Journal of Agricultural Sustainability, 9(1), 203-211. https://doi.org/10.3763/ijas.2010.0571

Pypers, P., Sanginga, J.-M., Kasereka, B., Walangululu, M., \& Vanlauwe, B. (2011). Increased productivity through integrated soil fertility management in cassava-legume intercropping systems in the highlands of Sud-Kivu, DR Congo. Field Crops Research, 120(1), 76-85. http://dx.doi.org/10.1016/j.fcr.2010.09.004

Ramisch, J. (2005). Inequality, agro-pastoral exchanges, and soil fertility gradients in southern Mali. Agriculture, Ecosystems and Environment, 105(1-2), 353-372. http://dx.doi.org/10.1016/j.agee.2004.02.001

Rodriguez, D., \& Sadras, V. O. (2011). Opportunities from integrative approaches in farming systems design. Field Crops Research, 124(2), 137-141. https://doi.org/10.1016/j.fcr.2011.05.022 
Roothaert, R., \& Magado, R. (2011). Revival of cassava production in Nakasongola District, Uganda. International Journal of Agricultural Sustainability, 9(1), 76-81. https://doi.org/10.3763/ijas.2010.0547

Roothaert, R., Ssalongo, S., \& Fulgensio, J. (2011). The Rakai Chicken Model: An approach that has improved fortunes for Ugandan farmers. International Journal of Agricultural Sustainability, 9(1), 222-231. https://doi.org/10.3763/ijas.2010.0563

Sanginga, N., Dashiell, K. E., Diels, J., Vanlauwe, B., Lyasse, O., Carsky, R. J.,...Ortiz, R. (2003). Sustainable resource management coupled to resilient germplasm to provide new intensive cereal-grain-legumelivestock systems in the dry savanna. Agricultural Ecosystems and Environment, 100, 305-314. http://dx.doi.org/10.1016/S0167-8809(03)00188-9

Saverio, K.. (2008). Cattle breeding, complexity and mobility in a structurally unpredictable environment: The WoDaaBe herders of Niger. Nomadic Peoples, 12(1), 11-41. http://dx.doi.org/10.3167/np.2008.120102

Sawadogo, H. (2011). Using soil and water conservation techniques to rehabilitate degraded lands in northwestern Burkina Faso. International Journal of Agricultural Sustainability, 9(1), 120-128. https://doi.org/10.3763/ijas.2010.0552

Segnon, A. C. \& Achigan-Dako, E. G. (2014). Comparative analysis of diversity and utilization of edible plants in arid and semi-arid areas in Benin. Journal of Ethnobiology \& Ethnomedicine, 10(1), 79-117. http://dx.doi.org/10.1186/1746-4269-10-80

Silici, L., Ndabe, P., Friedrich, T., \& Kassam, A. (2011). Harnessing sustainability, resilience and productivity through conservation agriculture: The case of Likoti in Lesotho. International Journal of Agricultural Sustainability, 9(1), 137-144. https://doi.org/10.3763/ijas.2010.0555

Settle, W., \& Garba, M. (2011). Sustainable crop production intensification in the Senegal and Niger river basins of Francophone West Africa. International Journal of Agricultural Sustainability, 9(1), 171-185. https://doi.org/10.3763/ijas.2010.0559

Stainback, G. A., Masozera, M., Mukuralinda, A., \& Dwivedi, P. (2012). Smallholder agroforestry in Rwanda: A SWOT-AHP analysis. Small-scale Forestry, 11, 285-300. http://dx.doi.org/10.1007/s11842-011$\underline{9184-9}$

Styger, E., Aboubacrine, G., Attaher, M. A., \& Uphoff, N. (2011). The system of rice intensification as a sustainable agricultural innovation: Introducing, adapting and scaling a system of rice intensification practices in the Timbuktu Region of Mali. International Journal of Agricultural Sustainability, 9(1), 67-75. https://doi.org/10.3763/ijas.2010.0549

Thuo, M., Brava-Ureta, B., Obeng-Asiedu, K., \& Hathie, I. (2014). The adoption of agricultural inputs by smallholder farmers: The case of an improved groundnut seed and chemical fertilizer in the Senegalese groundnut basin. The Journal of Developing Areas, 48(1), 61-82. https://doi.org/10.1353/jda.2014.0014

Tittonell, P., Van Wijk, M. T., Rufino, M. C., Vrugt, J. A., \& Giller K. E. (2007). Analysing trade-offs in resource and labour allocation by smallholder farmers using inverse modelling techniques: A casestudy from Kakamega District, Western Kenya. Agricultural Systems, 95(1-3), 76-95. http://dx.doi.org/10.1016/j.agsy.2007.04.002 
Tittonell, P., Vanlauwe, B., Leffelaar, P. A., Shepherd, K. D., \& Giller, K. E. (2005). Exploring diversity in soil fertility management of smallholder farms in Western Kenya: II. Within-farm variability in resource allocation, nutrient flows and soil fertility status. Agriculture, Ecosystems and Environment, 110(3-4), 166-184. http://dx.doi.org/10.1016/j.agee.2005.04.003

Tomekpe, K., Kwa, M., Dzomeku, B., \& Ganry, J. (2011). CARBAP and innovation on the plantain banana in western and central Africa. International Journal of Agricultural Sustainability, 9(1), 264-273. https://doi.org/10.3763/ijas.2010.0565

Traore, A., \& Bickersteth, S. (2011). Addressing the challenges of agricultural service provision: The case of Oxfam's Strategic Cotton Programme in Mali. International Journal of Agricultural Sustainability, 9(1), 8290. https://doi.org/10.3763/ijas.2010.0551

Wambugu, C., Place, F., \& Franzel, S. (2011). Research, development and scaling-up the adoption of fodder shrub innovations in East Africa. International Journal of Agricultural Sustainability, 9(1), 100-109. https://doi.org/10.3763/ijas.2010.0562

Waswa, C. W., Ndede, F. W. S., \& Jagongo, A. O. (2014). Dividend payout by agricultural firms in Kenya: An empirical analysis of firms listed on the Nairobi Security Exchange. International Journal of Business and Social Science, 5(11, Supplement 1), 63-74. https://ijbssnet.com/

Yengoh, G. (2012). Determinants of yield differences in small-scale food crop farming systems in Cameroon. Agriculture and Food Security, 1(19), 1-17. https://doi.org/10.1186/2048-7010-1-19

Zingore, S., Delve, R., Nyamangara, J., \& Giller, K. (2008). Multiple benefits of manure: The key to maintenance of soil fertility and restoration of depleted sandy soils on African smallholder farms. Nutrient Cycling Agroecosystems, 80, 267-282. http://dx.doi.org/10.1007/s10705-007-9142-2 